\title{
Meta
}

Journal des traducteurs

Translators' Journal

\section{Joseph F. GRAHAM (Ed.) (1985) : Difference in Translation, Ithaca and London, Cornell University Press, 253 p.}

\section{Daniel Slote}

Volume 35, numéro 2, juin 1990

URI : https://id.erudit.org/iderudit/004175ar

DOI : https://doi.org/10.7202/004175ar

Aller au sommaire du numéro

Éditeur(s)

Les Presses de l'Université de Montréal

ISSN

0026-0452 (imprimé)

1492-1421 (numérique)

Découvrir la revue

Citer ce compte rendu

Slote, D. (1990). Compte rendu de [Joseph F. GRAHAM (Ed.) (1985) : Difference in Translation, Ithaca and London, Cornell University Press, 253 p.] Meta, 35(2),

448-449. https://doi.org/10.7202/004175ar

Ce document est protégé par la loi sur le droit d'auteur. L'utilisation des services d'Érudit (y compris la reproduction) est assujettie à sa politique d'utilisation que vous pouvez consulter en ligne.

https://apropos.erudit.org/fr/usagers/politique-dutilisation/
Cet article est diffusé et préservé par Érudit.

Érudit est un consortium interuniversitaire sans but lucratif composé de l’Université de Montréal, l’Université Laval et l’Université du Québec à Montréal. Il a pour mission la promotion et la valorisation de la recherche. https://www.erudit.org/fr/ 
Joseph F. GRAHAM (Ed.) (1985): Difference in Translation, Ithaca and London, Cornell University Press, 253 p.

This collection of essays revolves around the ideas and writings of Jacques Darrida. His text "Des tours de Babel" is included in the book, both in French and its English version. 
The essays, from various points of view, discuss the constitutive function of difference in language. This idea is illustrated with specific reference to translation, but in contrast to the notions of the dominant tradition: here, the "difference" does not mean defeat. The overall effect of these essays is, on the contrary, a positive one that shows how translation is already included in the operation of language, just as difference is.

The editor, Joseph F. Graham, makes the point that translation cannot solve the problem of meaning if doubts remain as to the meaning of terms that define translation itself. The point is to find out what translation means, then we should know what translation $i s$.

The essays in the book set out to do just that, taking up various problems such as translation within a single language. Cynthia Chase's article qualifies the specific relation between a revery by Rousseau and an essay by Baudelaire as "a form of translation." Baudelaire transforms (read "translates") Rousseau's moral pleasure into physical disgust. What is significant here is not what Baudelaire preserves of the original but how he perverts the substance. Thus, it is the difference in translation which is the real "meaning" for both; it is this "difference" that transforms (translates) one text into another and "thereby changes textual meaning as a property of texts into contextual significance as a relation between texts."

Richard Rand detects translation in Keats's Ode to Autumn. Autumn (personified as a woman) translates certain elements into others while her poem simultaneously transforms other elements from the corpus of Keats's poetry and incorporates them into this new text on Autumn (on herself).

A different concept of translation is present in Barbara Johnson's article as well as in Alan Bass's, where psychoanalytic terms and social considerations are brought into the discussion.

This diversity of usage about translation, this confusion of tongues dear to many a linguist boils down to the fact that there is no way of knowing whether the parties to the eternal dispute over language, meaning and translation really understand each other since there is no way of knowing whether they are talking about the same things even when they use the same words. This nettlesome problem is discussed in two interesting essays, one by Robert J. Matthews about certain conditions necessary to sustain and thus continue the discussion of translation and the other - pivotal and seminal - by Jacques Derrida. One idea that surfaces among others is the conclusion that it is an error to oppose form and meaning, sacrificing the one for the other, since the very aim of translation is to cause to resonate in one language the meaning that adheres to the form in another. A good translator will distinguish between the mode, or manner, of meaning from the thing meant. Derrida points out that the author is no less beholden to the translator than the translator is to the author, and yet neither can possibly repay the other. Their texts are complementary and thereby equivalent in structure, as in reference, but not in substance or meaning.

A stimulating collection of essays on problems all translators have to think about. The fresh insights and novel approaches in these essays are a welcome addition to the ongoing debate on the place of translation in any theory of language.

DANIEL SLOTE 